\title{
Diffusion of Silver in Molten Lead-Tin Alloys*
}

\author{
By Shuichi Inagaki**, Satoshi Kado*** and Kichizo Niwa*****
}

The diffusion coefficients of silver in the lead-tin system have been studied at various concentrations of tin $N_{\mathrm{Sn}}$, 223, $0.405,0.614$ and 0.799 , and over the temperature ranges of $410^{\circ} \sim 557^{\circ} \mathrm{C}, 453^{\circ} \sim 509^{\circ} \mathrm{C}, 391^{\circ} \sim 509^{\circ} \mathrm{C}$ and $405^{\circ} \sim 590^{\circ} \mathrm{C}$, respectively. The results can be represented by the equations:

$$
\begin{aligned}
& D_{\mathrm{Ag}} \text { in } \mathrm{Pb}-\mathrm{Sn}\left(N_{\mathrm{Sn}}=0.223\right)=(2.89 \pm 0.26) \times 10^{-4} \exp \{-(3090 \pm 130) / R T\} \mathrm{cm}^{2} / \mathrm{sec}, \\
& D_{\mathrm{Ag}} \text { in } \mathrm{Pb}-\mathrm{Sn}\left(N_{\mathrm{Sn}}=0.405\right)=(2.79 \pm 0.26) \times 10^{-4} \exp \{-(2980 \pm 140) / R T\} \mathrm{cm}^{2} / \mathrm{sec}, \\
& D_{\mathrm{Ag}} \text { in } \mathrm{Pb}-\mathrm{Sn}\left(N_{\mathrm{Sn}}=0.614\right)=(2.46 \pm 0.17) \times 10^{-4} \exp \{-(2720 \pm 100) / R T\} \mathrm{cm}^{2} / \mathrm{sec}, \\
& D_{\mathrm{Ag}} \text { in } \mathrm{Pb}-\mathrm{Sn}\left(N_{\mathrm{Sn}}=0.799\right)=(5.43 \pm 0.34) \times 10^{-4} \exp \{-(3780 \pm 90) / R T\} \mathrm{cm}^{2} / \mathrm{sec} .
\end{aligned}
$$

With the aid of thermodynamic properties of the $\mathrm{Pb}-\mathrm{Sn}$ systems and supposing

$$
D_{i}(\mathrm{Ag}) \approx D_{i}(\mathrm{Sn}) \text {, }
$$

the diffusion coefficients of tin in the $\mathrm{Pb}-\mathrm{Sn}$ system at $500^{\circ} \mathrm{C}$ have been calculated by the equation

$$
\begin{aligned}
D_{\mathrm{Sn}} \text { in } \mathrm{Pb}-\mathrm{Sn} & =D_{i}(\mathrm{Sn}) \text { in } \mathrm{Pb}-\mathrm{Sn}\left(1+d \ln \gamma_{\mathrm{Sn}} / d \ln N_{\mathrm{Sn}}\right) \\
& \approx D_{i}(\mathrm{Ag}) \text { in } \mathrm{Pb}-\mathrm{Sn}-\mathrm{Ag}\left(1+d \ln \gamma_{\mathrm{Sn}} / d \ln N_{\mathrm{Sn}}\right) .
\end{aligned}
$$

The calculated values of diffusion coefficients at various compositions agree well with those experimentally obtained in a previous study.

$$
\text { (Received August 2, 1965) }
$$

\section{Introduction}

Niwa et al. (1) studied the diffusion of silver in molten lead, bismuth, tin, cadmium and copper, and made clear that the diffusion coefficient of the solute in dilute solutions depends upon the viscosity coefficient of the solvent and the atomic radius of the diffusions.

In order to find the relation between diffusion coefficients of the third component and thermodynamic properties of the binary system, the diffusion coefficients of silver were measured in alloys of lead-tin, lead-bismuth and bismuth-tin systems with various compositions. These systems were selected as the objects of investigation for the following reasons ;

(i) As mentioned above, Niwa et al. (1) have already

* This paper was published in Japanese in the Journal of the Japan Institute of Metals, 28 (1964), 353.

** Daido Steel Co., Aichi, Japan

*** Fuji Iron and Steel Central Research Laboratory Co., Sagamihara, Japan.

**** Department of Chemistry, Faculty of Science, Hokkaido University, Sappro, Japan.

(1) K. Tsuchiya, T. Ito, S. Kado and K. Niwa: J. Japan Inst. Metal, 26 (1962), 718, 722. ; T. Ohno, S. Kado and K. Niwa : ibid, 26 (1962), 726. measured the diffusion coefficients of silver in molten lead, tin and bismuth.

(ii) The $\mathrm{Pb}-\mathrm{Sn}$ system shows a positive deviation from Raoult's law, the $\mathrm{Pb}-\mathrm{Bi}$ system shows a negative deviation from it and the $\mathrm{Sn}-\mathrm{Bi}$ system has practically a thermodynamic properties nearly equivalent to those of an ideal solution.

(iii) Niwa et al. (2) experimentally found the concentration dependence of diffusion coefficients of tin in the $\mathrm{Pb}-\mathrm{Sn}$ system and bismuth in the $\mathrm{Pb}-\mathrm{Bi}$ system and in the $\mathrm{Sn}-\mathrm{Bi}$ system.

(iv) Since these three systems have comparatively low melting points, the experimental techniques and procedures are not so difficult.

According to the thermodynamics of irreversible processes $^{(3)}$, the flux of the first component in a ternary system is represented by

$$
J_{1}=L_{11} \frac{\partial \mu_{1}}{\partial x}+L_{12} \frac{\partial \mu_{2}}{\partial x}+L_{13} \frac{\partial \mu_{3}}{\partial x} .
$$

(2) Y. Watanabe, S. Kado, M. Shimoji and K. Niwa : ibid, 18 (1954), 274; T. Yokokawa, Y.Watanabe, S.Kado, M.Shitmoji and K. Niwa : ibid, 19 (1955), 299.

(3) S. R. de Groot: Thermodynamics of Irreversible Process, North Holland Publishing Co., Amsterdam (1952). 
As the last term in the Eq. ( 1 ) is zero for a binary system, $J_{1}$ can be expressed by a single diffusion coefficient by using the Gibbs-Duhem equation, whereas for the ternary system $J_{1}$ cannot be represented by a single diffusion coefficient. For the ternary, system, from Eq. ( 1 ) and the Gibbs-Duhem equation

$$
N_{1} d \mu_{1}+N_{2} d \mu_{2}+N_{3} d \mu_{3}=0,
$$

the diffusion coefficient ${ }^{(4)}$ for the first component, $D_{1}$, is given by

$$
D_{1}=\left(\frac{L_{11}}{N_{1}}-\frac{L_{12}}{N_{2}}\right) R T\left(1+d \ln \gamma_{1} / d \ln N_{1}\right)
$$

However, under a carefully selected experimental condition, where chemical potential gradients for the components excepting the diffusant do not exist, the system can be treated as the quasi-binary system. The experimental condition may be established by adding a very small quantity of a third component containing a small amount of the radioactive tracer as a diffusion component. Accordingly, measurements of the diffusion coefficient of silver in the molten alloys have been done by using the capillarry-reservoir method and $\mathrm{Ag}^{110}$ as the radioactive tracer. Under this experimental condition the diffusion coefficients of silver, $D_{\mathrm{Ag}}$, are given by

$$
D_{\mathrm{Ag}}=D_{i(\mathrm{Ag})}\left(1+d \ln \gamma_{\mathrm{Ag}} / d \ln N_{\mathrm{Ag}}\right),
$$

where $D_{i(\mathrm{Ag})}$ is the mobility of $\mathrm{Ag}$ in the alloy.

As the concentration of silver is sufficiently low, and the mole fraction of silver, $N_{\mathrm{Ag}}$, is exceedingly small, Henry's law is to be applicable to silver. Thus,

$$
D_{\mathrm{Ag}}=D_{i(\mathrm{Ag})} \text {. }
$$

By measuring the diffusion coefficients of silver in various compositions of the alloys, the change in the mobility of silver in the alloys can be determined. When the radii of diffusing atoms differ a little from each other, it can be assumed that the mobility of the components of the alloys, $D_{i(\mathrm{M})}$, is nearly equal to that of silver in the alloy, $D_{i(\mathrm{Ag})}$ *

By using the thermodynamic properties of the alloys the diffusion coefficients of the components of the alloys, $D_{\text {(M) }}$, are to be estimated from the following expressions.

$$
\begin{aligned}
D_{(\mathrm{M})} & =D_{i(\mathrm{M})}\left(1+d \ln \gamma_{\mathrm{M}} / d \ln N_{\mathrm{M}}\right) \\
& \approx D_{i(\mathrm{Ag})}\left(1+d \ln \gamma_{\mathrm{M}} / d \ln N_{\mathrm{M}}\right),
\end{aligned}
$$

where $D_{(\mathrm{M})}$ is the diffusion coefficient of the component $\mathrm{M}$ of the alloy, $D_{i(\mathrm{M})}$ is the mobility, of $\mathrm{M}, D_{i(\mathrm{Ag})}$ is the mobility of silver $\left(D_{i(\mathrm{Ag})}=D_{\mathrm{Ag}}\right.$ as shown above), and $\gamma_{\mathrm{M}}$ and $N_{\mathrm{M}}$ are the activity coefficient and the mole fraction of the component $M$ in the alloy, respectively. It is shown in the present work that the diffusion coefficients of tin in the $\mathrm{Pb}$-Sn system calculated from the Eq. (5) using the experimental values of $D_{\mathrm{Ag}}$ agree within the experimental error with their experimental values.

\section{Experiments and Results}

The experimental apparatus and procedures are the same as stated in the previous reports ${ }^{(1)}$. In order to prepare

(4) Y.Kawai : Science Reports of the Research Institutes, Tohoku University, A 209 (1957), No.6, 520. the $\mathrm{Pb}-\mathrm{Sn}$ alloys, the metals were covered with graphite powder and melted in an alumina crucible. After rapid cooling, the molten alloy was divided into two parts. A small amount of silver containing $\mathrm{Ag}^{110}$ was added to the one part and used as the molten metal-bath for a capillary-filling. The other part which was remelted was used as the bath for diffusion. The samples were taken out from the molten metal-bath several times before, during and after the experiments. The composition of each of the samples which was determined by the Shimazdu electrolytic analyzer(Type, AEA-1) was constant within the analytical uncertainty.

Analysis of the $\mathrm{Pb}-\mathrm{Sn}$ alloys was carried out by Foster's technique $^{(5)}$ modified by the authors. About $70 \mathrm{mg}$ of the $\mathrm{Pb}-\mathrm{Sn}$ alloy sample and about $30 \mathrm{mg}$ of copper powder were weighed in the $250 \mathrm{~mL}$-beaker for electrolysis, and dissolved in $15 \mathrm{~mL}$ of $\mathrm{HCl}(2: 1)$ and $5 \mathrm{~mL}$ of $30 \%-\mathrm{H}_{2} \mathrm{O}_{2}$ solution. After the excess of $\mathrm{H}_{2} \mathrm{O}_{2}$ was removed by boiling, the solution was diluted to an amount of $50 \mathrm{~mL}$ with water. After the addition of $2 \mathrm{~g}$ of hydrazine dihydrochloride, the solution was heated just before boiling, to which $2 \mathrm{~g}$ of urea was added and cooled. This solution was diluted with water until the electrode was completely immersed and then electrolyzed at a voltage of $-0.4 \mathrm{~V}$ for the deposition of copper.

After the deposition of the copper, $10 \mathrm{~mL}$ of $12 \mathrm{M}$ $\mathrm{NaOH}$ solution and $2 \mathrm{M}$ sodium tartarate were added to the solution in a $400 \mathrm{~mL}$-beaker and the solution was regulated to have a $\mathrm{pH}$ value between 4.9 and 5.1 by addition of $1 \mathrm{~g}$ of succinic acid. The deposition of lead by electrolysis was done at $-0.6 \mathrm{~V}$, using the platinum electrode on which copper was electrically deposited. Electrolysis was continued until the electric current dropped to $10 \mathrm{~mA}$ or less, followed by the additional electrolysis for ten munites at a current less than $10 \mathrm{~mA}$. When the current was ascertained to be the residual one, the electrolysis was stopped. Then, the electrode was taken out, washed, dried and weighed, and the concentration of lead was determined. In order to determine the concentration of tin, $20 \mathrm{~mL}$ of concentrated hydrochloric acid and $1 \mathrm{~g}$ of hidrazine dihydrochloride were added to the solution after the deposition of lead and electrolyzed at $-0.6 \mathrm{~V}$.

The diffusion coefficient of silver in the $\mathrm{Pb}-\mathrm{Sn}$ system, $D_{\mathrm{Ag}}$, was calculated by the following equation ${ }^{(1)}$.

$$
\begin{aligned}
\frac{\bar{C}-C_{\mathrm{S}}}{C_{0}-C_{\mathrm{S}}} & =\frac{8}{\pi^{2}} \int_{n=0}^{\infty} \frac{1}{(2 n+1)^{2}} \\
& \exp \left\{-(2 n+1)^{2} \pi^{2} D t / 4 l^{2}\right\} .
\end{aligned}
$$

The diffusion coefficients of silver in the $\mathrm{Pb}-\mathrm{Sn}$ system, $D_{\mathrm{Ag}}$, were obtained at the mole fractions of tin, $N_{\mathrm{Sn}}=$ $0.223,0.405,0.614$ and 0.799 and over the temperature ranges of $410^{\circ} \sim 557^{\circ} \mathrm{C}, 453^{\circ} \sim 609^{\circ} \mathrm{C}, 391^{\circ} \sim 609^{\circ} \mathrm{C}$ and $405^{\circ} \sim 695^{\circ} \mathrm{C}$, respectively, as shown in Tables 1 , 2,3 and 4 . Using the least-square method, the experimental points can be represented by the Arrhenius-type equations,

$$
\begin{array}{r}
D_{\mathrm{Ag}} \text { in } \mathrm{Pb}-\mathrm{Sn}\left(N_{\mathrm{Sn}}=0.223\right)=(2.89 \pm 0.26) \times 10^{-4} \\
\exp \{-(3090 \pm 130) / R T\} \mathrm{cm}^{2} / \mathrm{sec}, \quad(7)
\end{array}
$$

(5) D. G. Foster : Anal. Chem., 25 (1953), 669. 
$D_{\mathrm{Ag}}$ in $\mathrm{Pb}-\mathrm{Sn}\left(N_{\mathrm{Sn}}=0.405\right)=(2.79-0.26) \times 10^{-4}$ $\exp \{-(2980 \pm 140) / R T\} \mathrm{cm}^{2} / \mathrm{sec}, \quad(8)$

$D_{\mathrm{Ag}}$ in $\mathrm{Pb}-\mathrm{Sn}\left(N_{\mathrm{Sn}}=0.614\right)=(2.46-0.17) \times 10^{-4}$ $\exp \{-(2620 \pm 100) / R T\} \mathrm{cm}^{2} / \mathrm{sec} \quad(9)$ and

Table $1 \quad D_{\mathrm{Ag}}$ in $\mathrm{Pb}-\mathrm{Sn}\left(N_{\mathrm{Sn}}=0.223\right)$-alloys.

\begin{tabular}{|c|c|c|c|c|c|c|}
\hline $\begin{array}{l}\text { Temp. } \\
\left({ }^{\circ} \mathrm{K}\right)\end{array}$ & $\begin{array}{l}\text { Time } \\
\text { (sec) }\end{array}$ & $\begin{array}{l}\text { Length of } \\
\text { capillary } \\
\text { (cm) }\end{array}$ & $\begin{array}{c}\bar{C} \\
(\mathrm{cpn} / \mathrm{g})\end{array}$ & $\begin{array}{c}C_{0} \\
(\mathrm{cpm} / \mathrm{g})\end{array}$ & $\begin{array}{c}C_{\mathrm{S}} \\
(\mathrm{cpm} / \mathrm{g})\end{array}$ & $\begin{array}{l}D \times 10^{5} \\
\left(\mathrm{~cm}^{2} / \mathrm{sec}\right)\end{array}$ \\
\hline 830 & $\begin{array}{l}1200 \\
1200 \\
1200 \\
3900 \\
3900\end{array}$ & $\begin{array}{l}1.99 \\
2.01 \\
2.00 \\
1.72 \\
1.80\end{array}$ & $\begin{array}{r}1020 \\
1027 \\
1023 \\
861 \\
848\end{array}$ & $\begin{array}{l}1185 \\
1185 \\
1185 \\
1185 \\
1143\end{array}$ & $\begin{array}{l}0 \\
0 \\
0 \\
0 \\
0\end{array}$ & $\begin{array}{l}4.72 \\
4.37 \\
4.66 \\
4.45 \\
4.32\end{array}$ \\
\hline 783 & $\begin{array}{l}1800 \\
1800 \\
1800 \\
1800 \\
3600 \\
3600\end{array}$ & $\begin{array}{l}1.79 \\
1.78 \\
1.71 \\
1.73 \\
1.93 \\
1.89\end{array}$ & $\begin{array}{l}948 \\
953 \\
940 \\
975 \\
900 \\
894\end{array}$ & $\begin{array}{l}1.143 \\
1143 \\
1143 \\
1185 \\
1143 \\
1143\end{array}$ & $\begin{array}{l}4 \\
4 \\
4 \\
4 \\
5 \\
5\end{array}$ & $\begin{array}{l}4.06 \\
3.87 \\
3.90 \\
3.99 \\
3.72 \\
3.77\end{array}$ \\
\hline 725 & $\begin{array}{l}1800 \\
3600 \\
3600 \\
3600 \\
3600\end{array}$ & $\begin{array}{l}1.75 \\
1.96 \\
1.97 \\
2.05 \\
2.03\end{array}$ & $\begin{array}{r}1000 \\
934 \\
950 \\
953 \\
918\end{array}$ & $\begin{array}{l}1143 \\
1185 \\
1185 \\
1185 \\
1158\end{array}$ & $\begin{array}{l}7 \\
9 \\
9 \\
9 \\
9\end{array}$ & $\begin{array}{l}3.23 \\
3.45 \\
3.34 \\
3.50 \\
3.55\end{array}$ \\
\hline 683 & $\begin{array}{l}1800 \\
1800 \\
1800 \\
1800 \\
3600\end{array}$ & $\begin{array}{l}1.80 \\
1.82 \\
1.88 \\
1.63 \\
1.90\end{array}$ & $\begin{array}{r}1013 \\
974 \\
985 \\
961 \\
947\end{array}$ & $\begin{array}{l}1.185 \\
1.143 \\
1143 \\
1143 \\
1.185\end{array}$ & $\begin{array}{l}2 \\
2 \\
2 \\
2 \\
3\end{array}$ & $\begin{array}{l}2.88 \\
3.12 \\
2.74 \\
2.95 \\
3.16\end{array}$ \\
\hline
\end{tabular}

Table $2 N_{\mathrm{Ag}}$ in $\mathrm{Pb}-\mathrm{Sn}\left(N_{\mathrm{Sn}}=0.405\right)_{\text {-alloys. }}$

\begin{tabular}{|c|c|c|c|c|c|c|}
\hline $\begin{array}{l}\text { Temp. } \\
\left({ }^{\circ} \mathrm{K}\right)\end{array}$ & $\begin{array}{l}\text { Time } \\
\text { (sec) }\end{array}$ & $\begin{array}{l}\text { Length of } \\
\text { capillary } \\
\text { (cm) }\end{array}$ & $\begin{array}{c}\bar{C} \\
(\mathrm{cpm} / \mathrm{g})\end{array}$ & $\begin{array}{c}C_{0} \\
(\mathrm{cpm} / \mathrm{g})\end{array}$ & $\begin{array}{c}C_{\mathrm{S}} \\
(\mathrm{cpm} / \mathrm{g})\end{array}$ & $\begin{array}{l}D \times 10^{5} \\
\left(\mathrm{~cm}^{2} / \mathrm{sec}\right)\end{array}$ \\
\hline 882 & $\begin{array}{l}1800 \\
3600 \\
3600 \\
3600\end{array}$ & $\begin{array}{l}1.95 \\
1.95 \\
2.07 \\
1.85\end{array}$ & $\begin{array}{l}2824 \\
2518 \\
2538 \\
2655\end{array}$ & $\begin{array}{l}3430 \\
3334 \\
3334 \\
3430\end{array}$ & $\begin{array}{l}63 \\
70 \\
70 \\
70\end{array}$ & $\begin{array}{l}5.28 \\
5.01 \\
5.06 \\
5.19\end{array}$ \\
\hline 823 & $\begin{array}{l}3600 \\
3600 \\
3600 \\
1800 \\
1860 \\
1860 \\
1860 \\
3600 \\
3600\end{array}$ & $\begin{array}{l}1.83 \\
1.95 \\
1.82 \\
1.88 \\
2.03 \\
1.85 \\
1.70 \\
1.95 \\
1.91\end{array}$ & $\begin{array}{l}2611 \\
2638 \\
2604 \\
2870 \\
2903 \\
2801 \\
2764 \\
2610 \\
2490\end{array}$ & $\begin{array}{l}3430 \\
3430 \\
3430 \\
3430 \\
3430 \\
3385 \\
3430 \\
3385 \\
3385\end{array}$ & $\begin{array}{l}83 \\
83 \\
83 \\
79 \\
79 \\
20 \\
20 \\
24 \\
24\end{array}$ & $\begin{array}{l}4.37 \\
4.64 \\
4.41 \\
4.32 \\
4.35 \\
4.41 \\
4.50 \\
4.40 \\
4.45\end{array}$ \\
\hline 753 & $\begin{array}{l}1800 \\
1800 \\
3600 \\
3600\end{array}$ & $\begin{array}{l}2.01 \\
1.97 \\
1.90 \\
1.98\end{array}$ & $\begin{array}{l}2866 \\
2864 \\
2664 \\
2700\end{array}$ & $\begin{array}{l}3385 \\
3385 \\
3430 \\
3430\end{array}$ & $\begin{array}{l}32 \\
32 \\
36 \\
36\end{array}$ & $\begin{array}{l}4.04 \\
3.88 \\
4.01 \\
3.92\end{array}$ \\
\hline 726 & $\begin{array}{l}3600 \\
3600 \\
3600 \\
3600 \\
3600\end{array}$ & $\begin{array}{l}2.00 \\
1.90 \\
1.59 \\
2.03 \\
1.97\end{array}$ & $\begin{array}{l}2745 \\
2642 \\
2635 \\
2793 \\
2764\end{array}$ & $\begin{array}{l}3430 \\
3334 \\
3334 \\
3430 \\
3430\end{array}$ & $\begin{array}{l}53 \\
53 \\
53 \\
53 \\
53\end{array}$ & $\begin{array}{l}3.55 \\
3.51 \\
3.77 \\
3.20 \\
3.24\end{array}$ \\
\hline
\end{tabular}

$D_{\mathrm{Ag}}$ in $\mathrm{Pb}-\mathrm{Sn}\left(N_{\mathrm{Sn}}=0.799\right)=(5.43 \pm 0.34) \times 10^{-4}$ $\exp \{-(3780 \pm 90) / R T\} \mathrm{cm}^{2} / \mathrm{sec}$.

Using the equations $(7) \sim(10)$ and the Arrhenius-type equations for the diffusion coefficients of silver in lead and $\operatorname{tin}^{(1)}$,

$$
\begin{aligned}
D_{\mathrm{Ag}} \text { in } \mathrm{Pb} & =(3.19 \pm 0.17) \times 10^{-4} \\
& \exp \{-(3470 \pm 80) / R T\} \mathrm{cm}^{2} / \mathrm{sec}
\end{aligned}
$$

and

$$
\begin{aligned}
D_{\mathrm{Ag}} \text { in } \mathrm{Sn} & =(7.26 \pm 0.27) \times 10^{-4} \\
& \exp \{-(4160 \pm 60) / R T\} \mathrm{cm}^{2} / \mathrm{sec},
\end{aligned}
$$

the most accurate values of $D$ are calculated over the temperature range of experiment and the values of $\log D$ are plotted against $1 / T$ in Fig. 1. [As the values of $D_{\mathrm{Ag}}$ were not very different over all the compositions of the $\mathrm{Pb}-\mathrm{Sn}$ system, the above method was used for the pur-

\begin{tabular}{|c|c|c|c|c|c|c|}
\hline $\begin{array}{c}\text { Temp. } \\
\left({ }^{\circ} \mathrm{K}\right)\end{array}$ & $\begin{array}{l}\text { Time } \\
\text { (sec) }\end{array}$ & $\begin{array}{l}\text { Length of } \\
\text { capillary } \\
(\mathrm{cm})\end{array}$ & $\begin{array}{c}\bar{C} \\
(\mathrm{cpm} / \mathrm{g})\end{array}$ & $\begin{array}{c}C_{0} \\
(\mathrm{cpm} / \mathrm{g})\end{array}$ & $\begin{array}{c}C_{\mathrm{S}} \\
(\mathrm{cpm} / \mathrm{g})\end{array}$ & $\mid \begin{array}{l}D \times 10^{5} \\
\left(\mathrm{~cm}^{2} / \mathrm{sec}\right)\end{array}$ \\
\hline 968 & $\begin{array}{l}3600 \\
3630\end{array}$ & $\begin{array}{l}2.01 \\
2.21\end{array}$ & $\begin{array}{l}1301.1 \\
1324\end{array}$ & $\begin{array}{l}1807 \\
1807\end{array}$ & $\begin{array}{l}64 \\
64\end{array}$ & $\begin{array}{l}7.31 \\
8.14\end{array}$ \\
\hline 815 & $\begin{array}{l}1800 \\
3600 \\
3600 \\
3600 \\
3600\end{array}$ & $\begin{array}{l}2.24 \\
1.94 \\
1.91 \\
1.96 \\
1.98\end{array}$ & $\begin{array}{l}1399 \\
1367 \\
1272 \\
1276 \\
1296\end{array}$ & $\begin{array}{l}1674 \\
1806 \\
1674 \\
1674 \\
1674\end{array}$ & $\begin{array}{l}71 \\
78 \\
78 \\
78 \\
78\end{array}$ & $\begin{array}{l}5.25 \\
5.31 \\
5.04 \\
4.80 \\
5.14\end{array}$ \\
\hline 753 & $\begin{array}{l}1800 \\
3600 \\
3600 \\
3600 \\
3600 \\
3600\end{array}$ & $\begin{array}{l}2.07 \\
2.02 \\
1.90 \\
1.96 \\
1.92 \\
1.94\end{array}$ & $\begin{array}{l}1392 \\
1295 \\
1280 \\
1304 \\
1292 \\
1282\end{array}$ & $\begin{array}{l}1674 \\
1674 \\
1674 \\
1674 \\
1674 \\
1674\end{array}$ & $\begin{array}{l}0 \\
2 \\
2 \\
2 \\
2 \\
2\end{array}$ & $\begin{array}{l}4.36 \\
4.59 \\
4.36 \\
4.08 \\
4.20 \\
4.56\end{array}$ \\
\hline 723 & $\begin{array}{l}1800 \\
1800 \\
3600 \\
3600 \\
3600 \\
3600 \\
3600\end{array}$ & $\begin{array}{l}1.97 \\
2.11 \\
1.97 \\
2.03 \\
2.00 \\
2.06 \\
1.97\end{array}$ & $\begin{array}{l}1831 \\
1443 \\
1424 \\
1444 \\
1326 \\
1342 \\
1335\end{array}$ & $\begin{array}{l}1807 \\
1674 \\
1807 \\
1807 \\
1674 \\
1674 \\
1674\end{array}$ & $\begin{array}{l}47 \\
46 \\
52 \\
52 \\
52 \\
52 \\
52\end{array}$ & $\begin{array}{l}4.04 \\
3.96 \\
4.10 \\
3.82 \\
4.03 \\
3.85 \\
3.70\end{array}$ \\
\hline 687 & $\begin{array}{l}1800 \\
3600 \\
3600 \\
3600 \\
3600 \\
3600\end{array}$ & $\begin{array}{l}2.17 \\
2.19 \\
2.14 \\
2.23 \\
2.18 \\
2.16\end{array}$ & $\begin{array}{l}1469 \\
1383 \\
1470 \\
1501 \\
1492 \\
1475\end{array}$ & $\begin{array}{l}1674 \\
1674 \\
1807 \\
1807 \\
1807 \\
1807\end{array}$ & $\begin{array}{l}29 \\
32 \\
32 \\
32 \\
32 \\
32\end{array}$ & $\begin{array}{l}3.27 \\
3.22 \\
3.22 \\
3.17 \\
3.14 \\
3.54\end{array}$ \\
\hline
\end{tabular}

Table $3 \quad D_{\mathrm{Ag}}$ in $\mathrm{Pb}-\mathrm{Sn}\left(N_{\mathrm{Sn}}=0.614\right)$-alloys.

\begin{tabular}{c|c|c|c|c|c|c|c}
\hline Temp. & $\begin{array}{c}\text { Time } \\
\left({ }^{\circ} \mathrm{K}\right)\end{array}$ & $\begin{array}{c}\text { Length of } \\
\text { capillary } \\
(\mathrm{cm})\end{array}$ & $\begin{array}{c}\bar{C} \\
(\mathrm{cpm} / \mathrm{g})\end{array}$ & $\begin{array}{c}C_{\mathbf{0}} \\
(\mathrm{cpm} / \mathrm{g})\end{array}$ & $\begin{array}{c}C_{\mathrm{S}} \\
(\mathrm{cpm} / \mathrm{g})\end{array}$ & $\begin{array}{c}D \times 10^{5} \\
\left(\mathrm{~cm}^{2} / \mathrm{sec}\right)\end{array}$ \\
\hline 882 & 1800 & 1.93 & 6844 & 8400 & 70 & 5.59 \\
& 1800 & 1.94 & 6955 & 8400 & 70 & 4.91 \\
& 1800 & 1.97 & 6888 & 8400 & 70 & 5.39 \\
\hline 799 & 1800 & 2.03 & 7017 & 8400 & 34 & 4.81 \\
& 1800 & 2.08 & 7102 & 8400 & 34 & 4.33 \\
& 1800 & 2.04 & 7086 & 8400 & 34 & 4.39 \\
& 1800 & 2.02 & 7015 & 8400 & 34 & 4.76 \\
& 3600 & 2.09 & 6633 & 8400 & 46 & 4.24 \\
& 3600 & 2.06 & 6613 & 8400 & 46 & 4.24 \\
& 3600 & 2.03 & 6585 & 8400 & 46 & 4.23 \\
& 3600 & 2.14 & 6585 & 8400 & 46 & 4.70 \\
& 3600 & 2.05 & 6597 & 8400 & 46 & 4.31 \\
& 3600 & 2.11 & 6626 & 8400 & 46 & 4.33 \\
& 3600 & 2.07 & 6620 & 8400 & 46 & 4.28 \\
\hline 725 & 1800 & 1.95 & 7160 & 8400 & 190 & 3.64 \\
& 1800 & 1.76 & 6974 & 8400 & 190 & 3.80 \\
& 1800 & 1.92 & 7096 & 8400 & 190 & 3.89 \\
& 3600 & 2.00 & 6713 & 8400 & 266 & 3.72 \\
& 3600 & 2.05 & 6749 & 8400 & 266 & 3.73 \\
& 3600 & 2.02 & 6742 & 8400 & 266 & 3.59 \\
\hline 664 & 1800 & 2.01 & 7227 & 8400 & 210 & 3.25 \\
& 1800 & 2.04 & 7252 & 8400 & 210 & 3.12 \\
& 1800 & 2.05 & 7308 & 8400 & 210 & 3.03 \\
& 3600 & 1.96 & 6787 & 8400 & 228 & 3.20 \\
\hline \hline
\end{tabular}

Table $4 \quad D_{\mathrm{Ag}}$ in $\mathrm{Pb}-\mathrm{Sn}\left(N_{\mathrm{Sn}}=0.799\right)$-alloys.

pose of clarifing the figure. The experimental results (Tables 1 4) lie within a deviation of $\pm 8 \%$ from the values determined by the least-square method.]

As shown by the Eqs. ( 7$) \sim(12)$ and in Fig. 1, the diffusion coefficients of silver in the $\mathrm{Pb}-\mathrm{Sn}$ system are 
larger than those in pure lead, smaller than that in pure tin and regularly increase as the concentration of tin increases.

\section{Discussion}

When a radius of a solute atom is not very different from that of a solvent atom, the diffusion coefficient of the former in a dilute solution is anticipated to be nearly equal to that of the latter. Similarly both of mobilities may be assumed to be nearly the same. From the above assumptions and the Eq. (5), the diffusion coefficient of tin in the $\mathrm{Pb}-\mathrm{Sn}$ system, $D_{\mathrm{Sn}}$, can be given by

$$
\begin{aligned}
D_{\mathrm{Sn}} \text { in } \mathrm{Pb}-\mathrm{Sn} & =D_{i(\mathrm{Sn})} \text { in } \mathrm{Pb}-\mathrm{Sn}\left(1+d \ln \gamma_{\mathrm{Sn}} / d \ln N_{\mathrm{Sn}}\right) \\
& \approx D_{\mathrm{Ag}} \text { in } \mathrm{Pb}-\mathrm{Sn}-\mathrm{Ag} \\
& \left(1+d \ln \gamma_{\mathrm{Sn}} / d \ln N_{\mathrm{Sn}}\right) . \quad(5)^{\prime}
\end{aligned}
$$

Using the data ${ }^{(6)(7)}$ of the thermodynamic properties of the $\mathrm{Pb}-\mathrm{Sn}$ system, the activity of tin, $a_{\mathrm{Sn}}$, at $500^{\circ} \mathrm{C}$ is shown in Fig. 2. From Fig. 2, $\log \gamma_{\mathrm{Sn}}$ and $d \log \gamma_{\mathrm{Sn}} / d$

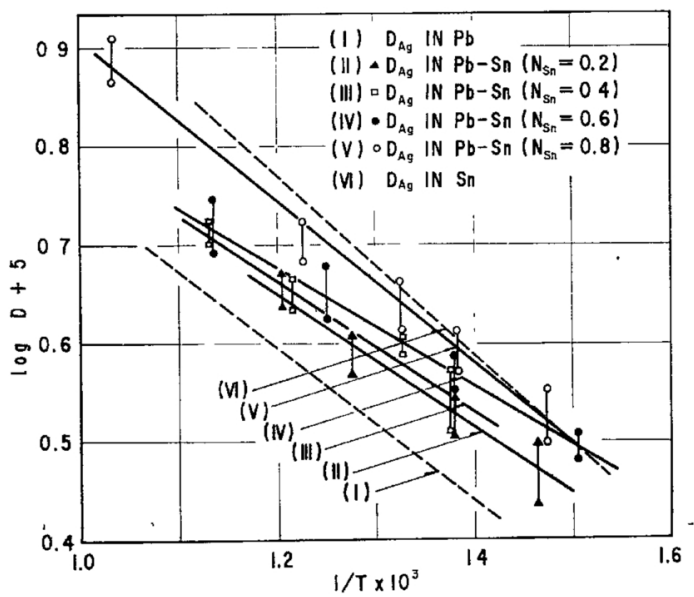

Fig. 1 Diffusion coefficients of silver in Pb-Sn alloys.

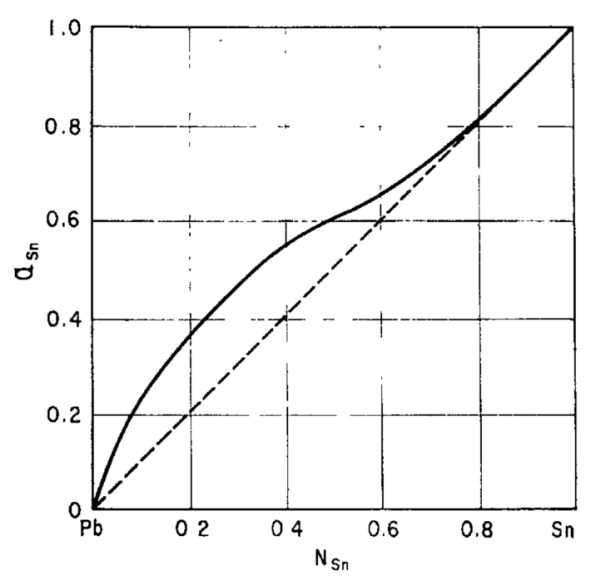

Fig. 2 Activity of tin in the $\mathrm{Pb}_{-} \mathrm{Sn}$ system at $500^{\circ} \mathrm{C}$.

$\log N_{\mathrm{Sn}}$ can be estimated for $N_{\mathrm{Sn}}=0.223,0.405,0.614$ and 0.799 . Therefore, $D_{\mathrm{Sn}}$ is to be calculated by putting in $(5)^{\prime}$ the above data and $D_{\mathrm{Ag}}$ for each concentration. From the Eqs. (7) $\sim(12)$ the values of $D_{\mathrm{Ag}}$ at $500^{\circ} \mathrm{C}$ are calculated as shown in Fig. 3. The diffusion coefficient of tin in the $\mathrm{Pb}-\mathrm{Sn}$ system, calculated from $D_{\mathrm{Ag}}$ and $d$

(6) J. F. Elliott and J. Chipman : J.A.C.S., 73 (1951), 2682.

(7) C. Wagner: Thermodynamics of Alloys, Addison-Wesley Press, Cambridge, Mass. (1952). $\log \gamma_{\mathrm{Sn}} / d \log N_{\mathrm{Sn}}$ for $N_{\mathrm{Sn}}=0.223,0.405,0.614$ and 0.799 , shows a minimum value in the proximity of $N_{\mathrm{Sn}}=0.6$, as shown in Fig. 4.

Niwa et al. ${ }^{(2)}$ have already measured the concentration dependence of the diffusion coefficients of tin in the

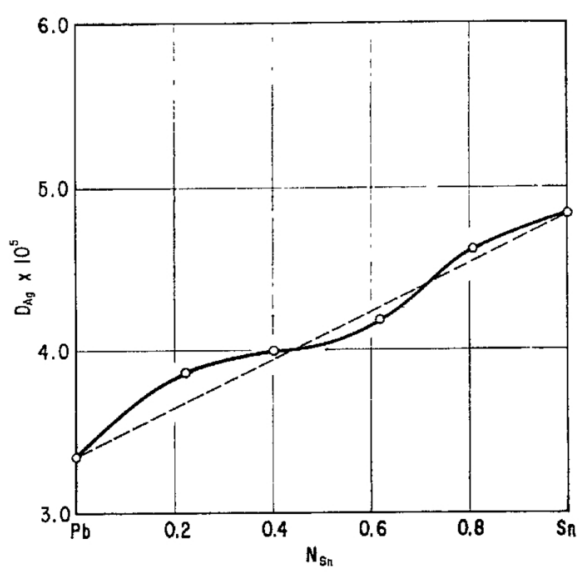

Fig. 3 Diffusion coefficients of silver in $\mathrm{Pb}-\mathrm{Sn}$ alloys at $500^{\circ} \mathrm{C}$.

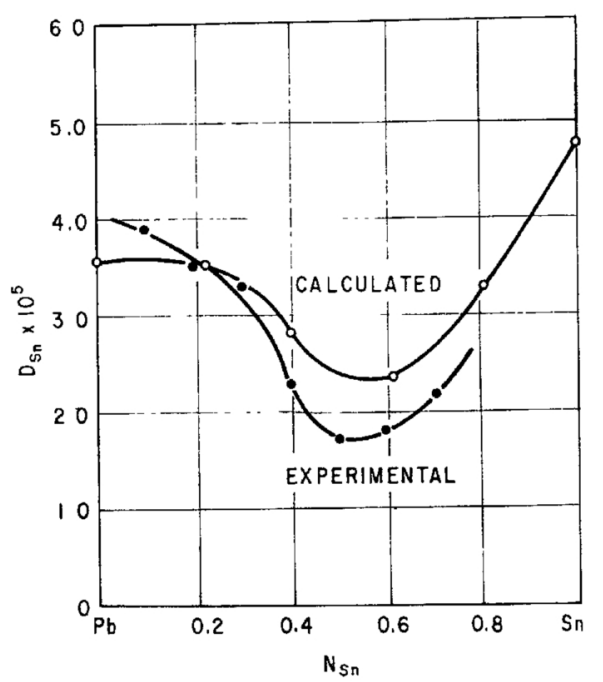

Fig. 4 Comparison between calculated and observed $D_{\text {Sn }}$ in the $\mathrm{Pb}-\mathrm{Sn}$ system at $500^{\circ} \mathrm{C}$.

$\mathrm{Pb}-\mathrm{Sn}$ system. In Fig. 4 their experimental results are compared with the values calculated in the above-mentioned way. In Fig. 4, both diffusion coefficients show minimum values at about the same composition and these values are approximately equal within the limit of experimental error over the whole range of compositions.

As mentioned above, it appears that the assumption represented by the Eq. (5) or (5)'-when the concentration of a third component in a binary system is sufficiently low, the diffusion coefficients of the first and second components can be estimated from that of the third component - may be established within the experimental error. As the atomic radii ${ }^{(8)}$ of silver and tin are 1.44 and $1.52 \AA$, respectively, the assumption that the size of the solute atoms is not so different from that of the solvent can be used. The effect due to the difference in atomic size will be discussed in a succeeding paper.

The viscosity and density in the $\mathrm{Pb}-\mathrm{Sn}$ system have

(8) C. J. Smitel: Metal Reference Book, Butterworth Scientific Publication (1949). 
already been measured by Fisher and Phillips ${ }^{(9)}$. According to them, the viscosity coefficient has a minimum value at the eutectic composition $\left(N_{\mathrm{Sn}}=0.75\right)$. On the other hand, the diffusion coefficient of silver in the $\mathrm{Pb}-\mathrm{Sn}$ system (i. e. the mobility of silver in this alloy) does not show any marked change at the eutectic composition. Further, contrary to the expectation from the data of the viscosity that the diffusion coefficient of tin in the $\mathrm{Pb}-\mathrm{Sn}$ system has a maximum value at the eutectic composition, the experimental results show the tendency to take a minimum value. Accordingly, the diffusion coefficient may be considered as strongly dependent upon the factor except for the viscosity of the $\mathrm{Pb}-\mathrm{Sn}$ system. However, the values of $D_{0}$ and $Q$ for the diffusion of silver in the $\mathrm{Pb}-\mathrm{Sn}$ system regularly decrease as $N_{\mathrm{Sn}}$ increases and they have a minimum values at $N_{\mathrm{Sn}}=$ 0.799. The changes in $D_{0}$ and $Q$ with $N_{\mathrm{Sn}}$ are found to correspond to that of the viscosity with $N_{\mathrm{Sn}}$ and the structure of the $\mathrm{Pb}-\mathrm{Sn}$ system is supposed to change with the concentration of tin. According to Fisher and Phillips $^{(9)}$, the density of the $\mathrm{Pb}-\mathrm{Sn}$ system shows a slightly negative deviation from an additivity law at $300^{\circ} \mathrm{C}$, while the additivity law is established at $400^{\circ}$ and $500^{\circ} \mathrm{C}$. So, the diffusion coefficients of silver (i.e. the mobilities of silver) in the $\mathrm{Pb}-\mathrm{Sn}$ system show the same linear change with the concentration as that of a molar volume. The diffusion coefficients of the components of the $\mathrm{Pb}-\mathrm{Sn}$ system depend largely upon the thermodynamic properties of the system, independently of the change of the molar volume.

As shown in Fig. 3 Niwa et al. have experimentally confirmed that the diffusion coefficients of silver in the $\mathrm{Pb}-\mathrm{Sn}$ system show a linear change with $N_{\mathrm{Sn}}$ and that the diffusion coefficients of tin calculated by the Eq. $(5)^{\prime}$, based on the assumption of equality between observed

(9) H. J. Fisher and A. Phillips: Trans. AIME, 200 (1954), 1060
$D_{\mathrm{Ag}}$ and $D_{i(\mathrm{Ag})}$ and also between $D_{i(\mathrm{Sn})}$ and $D_{i(\mathrm{Ag})}$, agree within the limit of experimental error with the observed values.

\section{Conclusion}

The diffusion coefficients of silver in the $\mathrm{Pb}-\mathrm{Sn}$ system were measured by a capillary-reservoir technique using a tracer, $\mathrm{Ag}^{110}$, for various concentrations of tin $N_{\mathrm{Sn}}, 0.223,0.405,0.614$ and 0.799 , and over the temperature ranges of $410^{\circ} \sim 557^{\circ} \mathrm{C}, 453^{\circ} \sim 609^{\circ} \mathrm{C}, 391^{\circ}$ $\sim 609^{\circ} \mathrm{C}$ and $405^{\circ} \sim 690^{\circ} \mathrm{C}$, respectively. The experimental results are as follows :

$$
\begin{array}{rcc}
\text { System } & D_{0} \times 10^{4} & Q \\
D_{\mathrm{Ag}} \text { in } \mathrm{Pb}-\mathrm{Sn}\left(N_{\mathrm{Sn}}=0.223\right) & 2.89 \pm 0.26 & 3090 \pm 130 \\
\left(N_{\mathrm{Sn}}=0.405\right) & 2.79 \pm 0.26 & 2980 \pm 140 \\
\left(N_{\mathrm{Sn}}=0.614\right) & 2.46 \pm 0.17 & 2720 \pm 100 \\
\left(N_{\mathrm{Sn}}=0.799\right) & 5.43 \pm 0.34 & 3780 \pm 90
\end{array}
$$

Under the experimental condition, the $\mathrm{Pb}-\mathrm{Sn}-\mathrm{Ag}$ ternary system is treated as a quasi-binary system. The observed values of diffusion coefficients, $D_{\mathrm{Ag}}$, are equal to $D_{i(\mathrm{Ag})}$ at $N_{\mathrm{Ag}} \approx 0$. On the assumption that $D_{i(\mathrm{Ag})}$ for the ternary system is equal to that of tin in the $\mathrm{Pb}-\mathrm{Sn}$ system, $D_{i(\mathrm{Sn})}$, the diffusion coefficient of tin in the $\mathrm{Pb}-$ Sn system, $D_{\mathrm{Sn}}$, is expressed by

$$
\begin{aligned}
& D_{\mathrm{Sn}} \text { in } \mathrm{Pb}-\mathrm{Sn} \\
& \quad=D_{i(\mathrm{Sn})} \text { in } \mathrm{Pb}-\mathrm{Sn}\left(1+d \ln \gamma_{\mathrm{Sn}} / d \ln N_{\mathrm{Sn}}\right) \\
& \quad \approx D_{\mathrm{Ag}} \text { in } \mathrm{Pb}-\mathrm{Sn}-\mathrm{Ag}\left(1+d \ln \gamma_{\mathrm{Sn}} / d \ln N_{\mathrm{Sn}}\right) .
\end{aligned}
$$

It is found that the values of $D_{\mathrm{Sn}}$, calculated from the above equation, agree within the limit of experimental error with the values experimentally obtained in a previous work. 